\title{
Sultana'nın Rüyası: Bangladeşli Bir Kadının Feminist Ütopyası
}

\author{
Yrd. Doç. Dr. Sema Zafer Sümer \\ Selçuk Üniversitesi Edebiyat Fakültesi \\ Ingiliz Dili ve Edebiyatı Bölümü \\ szsumer@selcuk.edu.tr
}

Öz

İnsanlık var olduğundan bu yana iyi bir geleceğin, yaşanabilir bir dünyanın hayalini kurmuştur. "Mutlu yer" ya da "olmayan yer" anlamına gelen ütopyalar ise ideal bir dünya yaratmada en etkin araçlardan birisidir. Feminist ütopyalar ise, tarih boyunca kendilerini üreten kaygıları ve hoşnutsuzlukları yansıtmışlardır. Politik olan feminist ütopyalar; yaşadığ 1 dönemin siyasal ve toplumsal düzenlemelerinden hoşnut olmayan yazarın farklı bir zaman ya da farklı bir coğrafyada tasarladığı, kurulu düzene bir başkaldırı içeren ve bu düzen karşısına kendi ideal toplum tasarımını ortaya koyan bir yazın türüdür. Bengalli Müslüman kadınlar için bir rol model olan ve yaşadığı sürece ülkesindeki kadınların özgürleştirilmesi için çalışan Bangladeş'in ilk Müslüman kadın yazar ve eğitimcisi Begüm Rokeya Sakhawat Hossain, 1905 yılında yazdığı feminist ütopyası Sultana'nın Rüyası'nda erkeklerin eve kapatıldığı, kadınlarınsa siyasette, bilimde, sanatta kısacası "dışarıda" yer aldığı özgür kadınlar ülkesi kurgular. Asla basit bir hayalden ibaret olmayan Sultana'nın Rüyası, yazarın İngilizce olarak yazdığı ilk eseridir ve kadınların özgürleştirilmesi için eğitimin önemine vurgu yapar. Gidilmeyen yolun öyküsünü anlatan yazar, ylllar önce kurguladığı bu kadınlar ülkesinde insanları bilinçlendirerek özgürlüğün, eşitliğin ve barışın önemine vurgu yapar. Rokeya, Müslüman kadının uyanışına öncülük ederek ırk, din, sınıf, cinsiyet ayrımının olmadığı yeni bir dünya, yeni bir dil yaratımıştır.

Anahtar Kelimeler: Feminist ütopya, Müslüman kadın, ideal dünya, maskülen sistem, ataerkil yapı.

\section{Sultana's Dream: The Feminist Utopia of a Woman from Bangladesh}

\begin{abstract}
Humanity has long dreamed about a better future and an imagined better world. Utopias, "the good place, which is no place", are one of the most influential ways of creating an ideal world and also serve as a crucial tool for expressing feminist ideology. Feminist utopias, for about ages, reflect the hopes, fears and desires of women who have glimpsed the possibilities of a bright new world freed from stifling patriarchal structures. By contrasting the present world with an idealized society, feminist utopias criticize the contemporary values and conditions and see masculine systems as the major cause of social and political problems. R.S. Hossain, a pioneering Bengali Muslim feminist and educationist, with her imaginative and ambitious narrative: Sultana's Dream (1905) provides a definite vision of what society could become if women were allowed to fully participate as citizens. The work


projects the desire for a peaceful, efficient and egalitarian society, and predicts the possibility of obtaining that desire through greater freedom for women. As a consequence, the present paper will focus on a women on the edge of time, Begüm Rokeya Sakhawat Hossain, her short work, Sultana's Dream, originally written in English. This study will highlight how she tries to create an ideal world, believing in the importance of education as holding the key to women's empowerment and progress. This paper will also concern itself with her personal journey on the road not taken before, the awakening of the Muslim women's self respect through self-reliance, and the universalist concept of shared humanity that admits no discrimination of caste, creed, race or gender.

Keywords: Feminist utopia, Muslim woman, an ideal world, masculine system, patriarchal structure. 


\section{GíRiş}

Ütopya; dinmeyen özlem ... Düş ülkesi ... Mutluluğun diyarı ... Gündüz düşü ... Umudun, cesaretin ve tükenmeyen insan enerjisinin kaynağı ... İnsanlık var olduğundan bu yana iyi bir geleceğin, yaşanabilir bir dünyanın hayalini kurmuştur. "Mutlu yer" ya da "olmayan yer" anlamına gelen ütopyalar (Ağaoğulları-Köker 1997: 191) ise tarih boyunca kendilerini üreten kaygıları ve hoşnutsuzlukları yansıtmışlardır. Ütopya asla basit bir hayalden ibaret değildir. Her zaman bir ayağı gerçekliğe basmaktadır. Ütopyanın değeri güncel uygulanabilirliğinde değil, olası bir gelecekle olan ilişkisindedir. Krishan Kumar'a göre "... ütopyayı güçlü kılan, "hayali" ve "uygulanamama" niteliğinin ta kendisidir ... ütopyanın "hiçbir yerdeliği" bizi onu aramaya kışkırtmaktadır. Bir sınır bizi hapsedebilir, engelleyebilir ya da onu aşmaya davet edebilir. Mümkün olanın herkes tarafından kabul edilen sınırı daima olumsal; daima zamanın ve mekânın somut koşullarına bağlıdır. İşte ütopya bu sınırları çiğner" (2005: 12-13). Kendi zamanı ve tüm zamanlar için "mevcut verili duruma yönelik radikal bir eleştiriyi" ifade ederken, "mevcut sınırları parçalamayı" amaçlar (Sargent 2004: 91). H.G. Wells'e göre karanlıklara fırlatılmış ışık gölgeleridir adeta. İnsanların zihni ne kadar dumanlıysa, o kadar çok ütopya çıkmıştır ortaya (Wells 2007: 65). Oscar Wilde ise "ütopyayı içermeyen bir dünya haritasına göz atmaya bile değmez ... ilerleme, ütopyaların gerçekleşmesidir" (Kumar 2005: 151) diyerek insanlığın durumu üzerine akıl yürütmede çok farklı olanaklar içeren bir harita sunar bizlere. İnsanlığın; verili koşulları yadsıyarak aşmayı, mevcut durumun sınırlarını zorlayarak dönüştürmeyi; ütopik düşünme özelliği sayesinde başardığını ve başarabildiğini anlatır.

Bilindiği üzere gelecekteki şey, yani henüz gerçekleşmemiş ama gerçekleşebilir olan şey, önce insan zihninde yaratılır; yaşanılan her an, zihinde geçmiş ve gelecek olarak ikiye bölünür. Ütopya yazarı da iki ayrı dünyada yaşar; dolayısıyla çift görüşlüdür. Bir taraftan kendi dünyasının aptalca ve boş işlerine bakıp öfkeli ve acı dolu bir edayla, ütopya zirvesinden aşağıyı seyrederken; diğer taraftan idealin erişilemezliğinin trajik duygusuyla da kendi dünyasından yukarı bakar. Hayalinde inşa ettiği ütopya; imgeleminin dışında yaşadığı ille de kusurlu olan dünyadan, yani kendi toplumundan çağrışımlarla renklendirilmiş mükemmel bir dünyadır (Kumar 2005: 152). Ütopya, imkânsız bir mükemmellik halini anlatıyor gibi gözükse de; insanlık için erişilmeyecek bir düş de değildir. Şimdi değilse bile "burada"dır.

İlk kez Thomas More tarafından kullanılan ve 1516'da yayınlanan, mükemmel ada devleti Ütopia'nın anlatıldığı eserinin adı bugün bu türün genel adı olarak kullanılmaktadır. Ütopya yazınının ilk örneklerine Eski Yunan ve Arap efsaneleri ile İbrani peygamberlerinde rastlanmaktadır. Homeros'un eserlerindeki düşsel devletler ya da Atlantis gibi efsaneler ve eski Ahit ilk ütopya örnekleri olarak görülmektedir. Ancak sistematik bir devlet tasarımı olarak ütopyanın ilk ve en önemli örneklerinden biri Platon'un Devlet diyaloğudur (Yıldırmaz 2005: 18). Tüm bu ütopyalarda, kendi toplumuna bir alternatif sunmayı hedefleyen ütopya yazarı, varolan gerçeklikten etkilenmiş ve onu aşmaya çalışmıştır. Ancak toplumsal cinsiyet gibi içselleştirilmiş bir yapının aşılması özellikle erkek yazarlar için her zaman mümkün olmamıştır. Siyasal örgütlenme, toplumsal kurum ve ilişkiler ya da ekonomik sistemler söz konusu olduğunda büyük bir çeşitlilik gösteren ütopyalarda; erkek yazarların kurguladığı klasik ve modern ütopyaların pek çoğunda; mevcut toplumsal cinsiyet rollerinin ortadan kaldırılması konusunda özel bir çaba gösterilmemiş; evli kadının kocası karşısındaki ikincil statüsü her zaman korunmuş, kadından ataerkil sistemin kendisinden beklediği "erdemler", uysallık, fedakârlık, güzellik, kibarlık beklenmeye devam

SEFAD, 2017 (38): 407-418 
etmiş, sağlıklı ve güzel nesiller için çocuk doğurmaları istenmiş, çocukları yetiştirmekten, ev idaresinden, konuklara hizmetten her zaman kadınlar sorumlu görülmüşlerdir (Yıldırmaz 2005: 126-127). Bireyin eril cins ile temsili, "özgür, eşit ve adil olanı" cinsiyetinin erkek olduğu özellikle klasik ütopyalar ve modern ütopyaların birçoğu ile kitlelere aktarılmış; Avrupa merkezci bir ideolojinin yansıması olarak bu yazın türü de uzun yıllar boyunca "Batılı" ve "erkek" olarak kalmıştır (Yılmazyiğit 2007).

\section{FEMINIST ÜTOPYALAR}

Özellikle 1970'lerden sonra basılan kadın yazarlara ait ütopyalar ve bu dönemde hızlanan feminist araştırmalarla gün yüzüne çıkarılan kadınlara ait ütopik metinler; 1700 'lerin sonlarından itibaren kadın yazarların da bu alanda var olduklarını kanıtlamış ve kadın tarihi açısından araştırılmamış pek çok alanın varlığını fark edebilmenin önemini gözler önüne sermiştir. Eril düşüncenin ele geçirme, hükmetme, iktidar kurma şeklinde kurguladığı insanın doğayla ve diğer insanlarla olan ilişkisine karşılık; kadınların yaşam karşısında farklı bir tarza sahip olduklarını, düz çizgisel bir ilerleme ve hâkim olma ilişkisi şeklinde değil, döngüsel bir zaman kavrayışı ve erkek tarzına alternatif olabilecek pozitif bir duyarlılık geliştirdiklerini (Donovan 2005: 328) ortaya koyan bu ütopyalar, geleceğin toplumlarına da bu kadın tarzının hâkim olacağı düşüncesinin göstergesidir.

Kadın yazarlar özellikle toplumsal cinsiyet ilişkilerine yaklaşımlarındaki belirgin farklılıklarıyla ataerkil düzeni çözümlerken var olanı sorgulayan, verili olanı değişmez olarak kabul etmeyen yeni bir ütopya tarzı ortaya koymuş ve feminist bir duruşla yazılan bu ütopyalarda yeni bir düşünce sistemi, yeni bir dünya, yeni bir dil yaratmaya çalışmışlardır. Feminist ütopyalar kendi doğasını ve kültürünü tanımlamakta özgür, birincil konumda bir kadınlığın ileriye dönük hayalleri değildir; bunlar erkek dünyasından erkek geleneğine karşıt olarak tanımlanan bir kültüre doğru kaçışlardır (Çakır-Akgökçe 1995: 166).

İlk dönem feminist hareket içinde var olan önemli on kadın ütopya örnekleri Mary Griffith'in, kadınların mal sahibi olmak ve onları kullanmakta özgür olduğu, ekonomik temelli ütopyası Three Hundred Years Hence (Üç Yüzyıl Ötede), Louisa May Alcott'un kadınların ekonomik olarak özerk oldukları bir dünyayı anlattığı Work (Emek) adlı ütopyası, Annie Danton Cridge'in Man's Right or How Would You Like It? (Erkek Haklar ya da Nasıl Olmasını İsterdiniz?) adlı karşı ütopyası, Mary Howland'ın eğitimli, kişisel ve toplumsal olarak sorumluluk sahibi kadınların varolduğu eşitlikçi toplum ütopyası olan Papa's Own Girl (Babasının Kızı)dır. 19. yüzyılın sonunda kadınların özgürlüklerini en iyi temsil eden simge olarak görülen Amazon figürü kadınlar tarafından yazılmış olan ütopyalarda görülmektedir. Alice Jones ve Ella Merchat'ın Unveilling a Parallel (Benzerini Ortaya Çıkarmak) ve May Bradley Lane'ın Mizroha: A Prophercy (Mizroha: Bir Kehanet) adlı ütopyaları buna örnek olarak gösterilebilir (Borghi 2003: 88).

Bu dönemin önemli yazarlarından biri de daha sonraki feminist ütopyacı düşünceyi de etkilemiş olan Charlotte Perkins Gilman'dır. Yazara göre "Kadınlar gelişmemiş erkek değildir, ancak insanlığın yarısını oluşturan kadınlar gelişmesi engellenmiş insanlardır" (Lane 2007: 14). Gilman'ın Herland (Kadınlar Ülkesi) adlı ütopyası, gerek yazıldığı dönemin toplumsal değişim sancılarını yansıtması, gerekse kadının bir yurttaş ve insan olarak toplumda eşit haklar kazanma mücadelesini "ideal toplum nasıl olmalı" arayışıla ele alıp uygarlık tanımını kadın bakış açısından yeniden modellemesi bakımından tarih içinde kadının bilinçlenme serüvenine ışık tutan öncü bir çalışmadır (Ersoy 2007). Bu ilk döneme ait bir başka Kadınların Ülkesi düşü ise bu çalışmanın sınırları içinde ele alınacak olan Begum 
Rokeya Sakhawat Hossain'in Sultana's Dream (Sultana'nın Rüyası) adlı feminist ütopyasıdır. 20. yüzyılın başlarında, 1905 yılında, Doğulu, Müslüman bir kadının kaleme aldığı bir kadınlar ülkesi, bir direniş oluşumudur.

\section{MÜSLÜMAN KADININ UYANIŞINA ÖNCÜLÜK EDEN BİR SES: BEGÜM ROKEYA SAKHAWAT HOSSAIN}

1880 yılında, İngiliz sömürgesi olan Hindistan Bengal'de, bugünkü Bangladeş'in Rangpur bölgesinde varlıklı bir Müslüman ailenin kızı olarak dünyaya gelen, Begüm Rokeya; iki oğlunu dönemin en prestijli okullarına gönderirken, ailesinin kullandığı adıyla Raku ile ablasını geleneksel ev içi eğitimin (zenana) sınırlarına hapseden eğitimli, muhafazakâr bir babanın kızıdır (Miah 2014: 42). Begüm Rokeya'nın doğup büyüdüğü bu coğrafyada, Müslüman erkek çocukların mektep ve medreselerde; kız çocukların ise evde eğitim aldığı 1880'lerde; Bengalce konuşan nüfusun yarısı Müslüman olmasına rağmen bu geleneksel eğitim sistemi nedeniyle kolejlerde okuyan Müslümanların oranı yalnızca yüzde beştir (Hossain 2003: 10). Okula gönderilmek istenmeyen birçok Müslüman ailenin k1z çocuğu gibi Begüm Rokeya da evde Arapça ve Urduca öğrenir. Hayatında önemli bir yere sahip olan büyük abisi İbrahim Saber'in gizlice kendisine ve ablasına öğrettiği İngilizce ve Bengalce onu kutsal metinlerle birlikte diğerlerini de okumaya teşvik eder. Özel alanın dışındakilerle kurulan iletişim Rokeya'yı yazmak için cesaretlendirir (Bagchi 2005: viii). Bu geleneksel ve tutucu eğitimin üzerlerinde yarattığı tahakkümü ilk kez ablası Kaminunesa ile deneyimleyen Begüm Rokeya; gizlice İngilizce öğrendiği için ablasının büyükannesinin yanına gönderilerek 14 yaşında evlendirilene kadar gözetim altına tutuluşuna ve 23 yaşında dul kalışına tanıklık eder (Hossain 2003: 148). Ailesine karşı hissettiklerini, 1924 yılında kaleme aldığı Padmarag adlı diğer ütopyasında "sevgili ağabey"e ithaf ettiği şu cümlelerle dile getirir: "... beni büyüten ve şekillendiren sensin. Anne, baba, öğretmen ... bunların hiçbiri hakkında bilgim yok, ben sadece seni biliyorum" (Yıldırmaz 2007: 5).

Onaltı yaşındayken, kırk yaşına yaklaşmış dul bir erkek olan Syed Sakhawat Hossain ile evlendirilen ve dünyaya getirdiği kız bebeklerin kısa aralıklı ölümleriyle sarsılan Begüm Rokeya, bu acıyı başka kız çocuklarına yardım eli uzatarak hafifletmeye çalışır. Eşinin ölümünden sonra kendisine bıraktığı parayla 1909'da Sakhawat Memorial Kız Okulu'nu açar (Miah 2014: 43). Başlangıçta beş olan öğrenci sayısı, Rokeya'nın Müslüman aileleri kapı kapı dolaşarak kızların eğitimi konusunda ikna etmesi üzerine, 1915'te seksendörte yükselir. Lise düzeyinde, Bengalce ve İngilizce eğitim veren bu okul; yüz Bengalli Müslüman kadından yalnızca birinin eğitimli olduğu, on bin kadından yalnızca birinin İngilizce bildiği ve Bengal'deki 23.437 kolej öğrencisinin sadece 284'ünün kızların oluşturduğu dönemin koşulları göz önüne alındığında göz ardı edilemeyecek bir öneme sahiptir (Hossain 2003: 111-129). Verilen bu mücadele sadece eğitimle sinırlı değildir.

Ülkenin genelinde ve özellikle Müslüman toplumunda Rokeya'nın büyük mücadele verdiği harem sistemi; 6-7 yaşlardan itibaren kız çocuklarının hareme kapatılarak evliliğe hazırlanışlarının, çocuk yaşta yapılan evliliklerin, dışarıda eğitim almalarını engelleyen geleneklerin, küçük yaşlarda dul kalmalarına neden olan ve ikinci evliliğin utanılacak bir davranış olarak kabul edildiği bir toplumun, toplumsal kuralların, değer yargılarının öyküsü; kısacası baskı altında tutulanın hayatıdır. Hayatı sadece yaşamı idame ettirmeye indirgenmiş kadının "varlık" ve "hiçlik" arasındaki yolculuğudur.

$\mathrm{Bu}$ yolculuğu sürekli sorgulayan Hossain, yaşadığı sürece hiçbir baskıya, sansüre, eleştiriye ve tehdide aldırmadan yazar. Harem geleneğini "gözönünde olan, açık bir yara

SEFAD, 2017 (38): 407-418 
gibi değil; karbonmonoksit gibi sessizce öldüren bir şey" (Hossain 2003: 152-153) olarak tanımlayan Begüm Rokeya The Secluded Ones (İnzivadakiler) ve God Gives, Men Robs (Allah Verir, Erkek Çalar) adlı çalışmalarında harem sisteminin Kuran'da yazan, şeriatta yeri olan bir uygulama olmadığını, Allah'ın insanları eşit yarattığını dile getirir (Yıldırmaz 2007: 8). Niaz Zaman'ın A Celebration Of Women adlı kitabında Begüm Rokeya "Emek verdim, çabaladım ve yazdım. Toplumdaki kötülükleri ve ikiyüzlülükleri yazdım. Kadını her an kısıtlayan "purdah"ı (Hindistan'da kadınların bedenlerini, yüzlerini örtmek amaçlı kullandığı geleneksel örtü, peçe...) yazdım. Geleneklerin anlamsızlığını ve baskıcılığını yazdım. Kadınları sınırlayan hukuk kurallarını yazdım ve bunları görmezden gelen Bengallilerin zayıflığını yazdım" (2003: 18-19) sözleriyle cinsiyete göre bölünmüş ve bir cinsin diğerinin egemenliği altında olduğu bir dünyada "kadın olmak" ve "yazmak" arasındaki ilişkiye ve bu sancılı sürece vurgu yaparken, kadınların kendilerini ifade etmelerini engelleyen kısıtlamalara meydan okumuş, yaşamın her alanını içine alan bir kadın gerçekliğine vurgu yapmıştır.

Ülkesindeki kadınların özgürleştirilmesi için tutkuyla çalışan Bangladeş'in ilk Müslüman kadın yazarı, yazar ve eğitimci olarak yaptığı çalışmaların yanı sıra Kalküta kadın hareketinde, sivil çalışmalarda etkin olarak yer alır; gerçekleştirilen ulusal ve uluslararası toplantılara başkanlık yapar (Yıldırmaz 2007: 6). 1916'da Bengal Müslüman Kadınlar Derneği'ni (Anjuman -e- Khawatin- e- Islam) kuran Begüm Rokeya; kadınların eğitimi, istihdamı, toplumsal ve siyasal hakları için mücadele eder ve bu dernek aracılığıyla kimsesiz kadınlara barınma olanağı sağlar. Dul kadınlara da maddi yardımda bulunan bu dernek tıpkı yazdığı diğer feminist ütopyası Padmarag'da kurguladığı Tarini Bhavan adlı "kadınlar okulu", "sı̆̆ınağı" veya "evi" gibi tüm terk edilmiş, ihmal edilmiş, yardıma muhtaç, fakir kadınlara kapılarını açar (Jahan 1988: 42).

Birçok farklı türde eserler veren; öykü, roman, şiir ve denemeler yazan ve birçok dergide düzenli olarak yayımlanan yazılarıyla Güney Asya'da bir Müslüman kadın hareketinin oluşmasına önemli katkılar sunan Begüm Rokeya; yaşadığı dönem ve daha ileri yüzyıllarda kadın hareketinin temel prensiplerini oluşturan savları ile İngiltere'den seslenen Mary Wollstonecraft'ın görüşünü benimsemiştir. Yazar, onun gibi kadının boyun eğme ve teslim olma yerine, kendi toplumsal rolünün kendisi tarafından serbestçe belirlendiği bir bilinç aracılı̆̆ıyla, erkeklerin buyurganlıklarını reddederek kendi karar yetkilerine sahip olmaları gerektiğini savunmuştur (Donovan 2005: 30-31).

Toplumun geleneksel yapısına karşı yazdıkları, söyledikleri, yaptıkları nedeniyle Hıristiyan yandaşı ve Avrupa hayranı olmakla suçlanan yazar (Forbes 1996: 57); bir yandan İngiliz sömürgeciliğine karşı milliyetçi çizgide yazılar yazarken diğer yandan Batılı kadının eğitim gibi bazı hakları kazanmış olmasına rağmen tamamen özgürleşemediğini, hâlâ bir kölenin zihniyetine sahip olduğunu (Hossain 2003: 156) söyleyerek tüm bu suçlamalara sanki cevap verir. Tek boyutlu bir toplumsal eleştirinin sözcüsü olmayan Begüm Rokeya, aslında çok katmanlı değişime açık, siyasal ve etik bir uygulamanın, batıya özgü koşullarla sınırlandırılamayacak kadar çok anlam içeren feminizmin sesidir. Bugün Bangladeş'te Müslüman kadının uyanışının ve kurtuluşunun öncüsü olarak anılan yazar, 9 Aralık 1932'deki ölümüne kadar kadınları tarih içinde görünür kılmak, var etmek, kalıp yargıları yıkıp yeni ufuklar açmak ve tabuların sorgulanabilmesini sağlayabilmek için mücadele etmiş; gerçek kadın kimliğinin bulunması ve tanımlanmasının üzerinde önemle durmuştur. Geleceğin özgür düşünceli kadınlarını yaratmayı hedefleyen Begüm Rokeya, yazdıkları ile bize düşlediği bu dünyanın kapılarını aralar. 


\section{BİR DÜŞ ÜLKESİ: SULTANA'NIN RÜYASI}

Illk kez 1905 yılında The Indian Ladies Magazine'de İngilizce olarak yayınlanan Sultana's Dream (Sultana'nın Rüyası) 20. yüzyılın başında bir Doğu ülkesinde, Güney Asya'nın önemli feministlerinden biri olan Bangladeşli bir kadının yazdığı ilk feminist ütopya örneği olması açısından oldukça önemlidir. Ülkesinin genelinde ve birçok Müslüman toplumunda baskı altında yaşayan, hareme kapatılan, henüz çocukken evlendirilen, ağır kumaştan yapılmış kıyafetler ve ağır takılarla fiziksel olarak kısıtlanan, eğitim alamayan kadınlara ithaf edilen Sultana'nın Rüyasi'nda; erkeklerin eve kapatıldığı, kadınlarınsa siyasette, bilimde, sanatta yani "dışarıda" yer aldığı bir kadınlar ülkesi betimlenir. Erkekler "selamlık"ta hapistir; kadınlar ise sokaklarda, ülke yönetiminde, sanatta ve bilimde aktif rol oynar. Kadınlar zekâlarını kullanırken erkekler ev içi pratikleriyle oyalanır (Ögüt 2007: 75).

Begüm Rokeya'ın kendi tanımlamasıyla "günahtan ve kötülükten arındırılmış bir yer"i (2007: 16) anlattığı kısa, satirik ütopyası, Sultana'nın Rüyası, klasik ütopya modeline uygun olarak bir rüya yolculuğuyla, aniden bir başka dünyaya giden, bir rehber eşliğinde bu dünyayı gezerek; oranın siyasal, toplumsal, ekonomik özellikleri hakkında bilgi edinen ve yine geldiği gibi aniden kendi zamanına/dünyasına dönen bir kahramanın ağzından anlatılır (Yıldırmaz 2007: 8). Ancak var olanın tersine çevrildiği bu dünyada; klasik ütopyaların aksine, yöneticiler, bilim insanları, sanatçılar erkekler değil, kadınlardır. Sultana rehberi olan ve kendisinin Rahibe Sara olarak adlandırdığı bu kadınla ansızın geldiği bu kadınlar ülkesini dolaşırken, okuyucuya bu yeni dünyayı tanıtır ve değişmezliğine inandığı birçok şeyin nasıl farklılaştığına dikkat çeker:

Gün ortasinda caddede yürüdüğ̈̈mü düşününce utanç duydum ... haremde yaşayan peçeli bir kadın olarak başı açık gezmeye alışık değilim ben ... ama görünürde tek bir erkek bile yoktu ... (Hossain 2007: 16) ... Erkeklerin nerede olduğunu öğrenmek için meraktan çatliyordum. Yürürken, belki yüzden çok kadın gördüğ̈̈̈m halde tek bir erkeğe bile rastlamamıştım (Hossain 2007: 17).

Bu değişim ve sorgulamayı daha etkin kılabilmek için yazar; kadınlar ülkesinde kendisine eşlik eden rehbere, Sultana'nın sürekli sorular sormasını sağlar:

"Erkekler nerede? ...

"Erkekleri eve kapattık."

"Bizim haremlere kapatılmamı gibi mi?"

"Evet, tıpkı öyle"

"Çok tuhaf!" ...

"Ama Sevgili Sultana, kimseye bir zararı olmayan kadınları içeri hapsedip, erkekleri başıboş bırakmak ne büyük haksızlık (Rokeya 2007: 17) ... Her türlü kötülüğ̈̈ yapma gücüne sahip olan ve her türlü kötülü̆g̈̈ yapan erkekler ortalıkta serbest dolaşırken, masum kadınlar hareme hapsediliyor! Senin ülkende yapılan şey tam da bu!" (Hossain 2007: 18).

Tasarlanan bu yeni dünya sonuçta Begüm Rokeya'nın zihninde yaratılmış bir dünyadır, ancak kurmaca öylesine akıllıca işlenmiştir ki o "eski ile yeninin kıyasında" zaferini ilan edecektir. Verilmek istenen mesaj çok açıktır: Krize yuvarlanmış eski ve köhnemiş dünya artık aşılmalıdır. "Sosyal olayların idaresinde ne söz sahibiyiz, ne de güç. Hindistan'da erkek her şeye hükmeder, efendidir, bütün gücü ve yetkiyi elinde toplamıştır ve kadınları da haremlere hapsetmiştir" (Hossain 2007:18 ) cümleleriyle Sultana tarafından betimlenen bu eski dünya Kate Millet'in Sexual Politics (Cinsel Politika) adlı eserinde 
tanımladığı "erkeğin mutlak üstünlüğü ve kadının ona bağımlı kılınış sisteminin, toplumsallaşma yoluyla korunduğu ve ideolojik araçlarla sürdürüldüğü ve gerektiğinde güce başvurulduğu" (1975: 65-67) bir dünyadır. Sultana'nın Rüyasi'nda mevcut düzenin alternatifi olarak yansıtılan karşıt dünya; Sultana'nın sorgulayan, sarsan ve aydınlatan bir işlevselliği olan soruları ve "ama" ile başlayan itirazlarıyla "bir şeylerin düzgün gitmediği" duygusunu verir okura. Ama "... doğamız gereği zayıf olduğumuz için haremin dışına çıkmamız hiç de güvenli değil" (Hossain 2007: 18), ama "Erkekler kadınlardan daha güçlü oldukları için başka yolu yok" (Hossain 2007: 18), ama "erkeklerin beyinleri bile kadınlarınkinden daha büyük ve ağır, değil mi?" (Hossain 2007: 22), ama "... erkeklerin ordusu kadınlarınkinden daha güçlü ..." (Hossain 2007: 22), ama "... her şeyi kendi kendimize yaparsak erkekler ne yapacak" (Hossain 2007: 18), ama... ama... ama. Eser boyunca tüm bu "ama"lara verilen cevaplar ve karşıt sorular; Sultana'nın ve onunla birlikte okuyucunun kadınlar, erkekler ve toplumsal kabuller konusundaki mevcut olanı sorgulamasını sağlar (Yıldırmaz 2007: 9).

Begüm Rokeya'nın yaratıcllığını, birikimini, yeteneklerini ve hicvini yansıtan Sultana'nın Rüyası, okura yaptırdığı zihinsel jimnastik ve karşılaştırma yoluyla mevcut düzene yönelik güven ve inançları sarsmış; aynı zamanda henüz mevcut olmayan, ancak kurulabilir "daha iyi dünyanın" varlığına işaret etmiştir. Yıllar sonra feminizmin başyapıtı olarak değerlendirilen The Second Sex (İkinci Cins) adlı eserinde Simone de Beauvoir'in erkeği "insan modeli" olarak inşa eden, kadını "erkek olmayan", tam olarak "insan olmayan", "mutlak başka" olarak temsil eden ataerkil uygarlığın dönüştürülebilir ve değiştirilebilir oluşuna yaptığı vurgu (Direk 2016: 16) 1905 yılında yazılan Begüm Rokeya'nın ütopyasının sadece kadının dinmeyen masalımsı özleminden çok daha fazlası olduğunu ortaya koymuştur. Tüm dünyadaki kadınların, cinsiyetleri dolayısıyla ortaklaştıkları durumlara ve sorunlara işaret eden Rokeya ve Simone, patriarkal yapının ve bundan doğan toplumsal cinsiyet tahakküm mekanizmasının gerçekliğine farklı coğrafyalarda ve farklı zaman dilimlerinde değinerek, bir sosyal ilişkiler dizisi olan toplumsal cinsiyeti nesnel bir sosyal mekanizma olarak kavramamızın yolunu açarlar. Begüm Rokeya, Sultana'nın Rüyası'nda, erkeği ve kültürü merkeze yerleştirip, kadını ve doğayı ikincil, edilgen, "şuursuz çevre" olarak konumlandıran ataerkil sisteme; yani toplumun ataerkil doğasına, kadının erkek tarafından ve doğanın toplum tarafından sömürülmesine de karşı çıkar. Çevre sorunlarının sosyal bağlamda ele alındığı bu feminist ütopyada, günümüzde yapılan "eleştirel çevre felsefesi" yerine; "yapıcı çözümler üreten" çevre teknolojisinden bahsedilir. 21. yüzyılın başat sorunlarından biri olan "çevrecilik"in günümüzde bile entelektüel boyutta ele alınmadığını, literatürde yeni yeni ses veren "derin ekoloji" ve "ekofeminizm" gibi akımların hayli çekici argümanlarının bile toplumsal cinsiyet tartışmalarında bu zamana kadar ağırlığını koyamadığı düşünülecek olursa, Rokeya'nın yarattığı bu fantastik dünyaya ilişkin görüşlerin yatağına sığmayan bir çağlayan gibi gürül gürül aktığı hissedilecektir. Ayrıca bilimin eril proje olmaktan çıkartılıp insani bir projeye dönüştürüldüğü bu ütopyada yıllarca eve kapatılan kadının bilimsel alandan soyutlanışına inat, tüm bilim insanları kadınlardır. Keller'in Toplumsal Cinsiyet ve Bilim Üzerine Düşünceler adlı eserinde belirttiği gibi Rokeya da duygusal emek ve düşünsel emek arasındaki, bilimin erkeklere tahsis edilmiş bir alan olarak kalmasını sağlayan işbölümünü reddeder ve (2007: 12) eserde toplumların "hangi" sorunlarının "nasıl" çözülmesi gerektiğine dair fikirleriyle her reform hareketi, yani "daha iyinin bilinci" bilimsel buluşları ordudakiler tarafından "duygusal kâbus" olarak nitelendirilen genç bilim kadınları tarafından gerçekleştirilir. Tüm eril önyargıların yıkılarak 
toplum ve toplumsal kuramların yeniden inşa edildiği kadınlar ülkesinde bir umut ufku oluşturulur. "Bir dünya"nın değil, "başka dünya"ların da mümkün olduğuna dair umut dolu düşünceler Sultana'nın cümleleriyle aktarılır okuyucuya:

Sanki yumuşak bir halı üzerinde yürüyormuş gibi hissederek yere baktım, yolun yosunlarla ve çiçeklerle kaplı olduğunu gördüm... "her yer çiçek bahçesi gibi görünüyor" dedim beğeniyle, "bütün bitkiler ustaca bir düzenle dikilmiş" (Hossain 2007: 17).

Değişik konular hakkında sohbet etmeyi sürdürdük ve bu ülkede hiç bulaşıcı hastalık olmadığını, kimsenin bizim gibi sivrisinek ısırmasından şikâyet etmediğini öğrendim. Kadınlar ülkesinde bir iki kaza hariç, genç yaşta ölümlerin olmadığını duyduğumda ise çok şaşırdım (Hossain 2007: 20).

-...

Mutfak harika bir sebze bahçesinin ortasındayd ve her bir sarmaşık her bir domates bitkisi, kendi başına bir süs bitkisi gibiydi. Mutfakta ne duman vard, ne de baca; son derece temiz ve aydınlık bir yerdi, pencereler çiçeklerle süslenmişti; kömür ve ateşten eser yoktu (Hossain 2007: 20).

Güneş ısısını toplamayı ve depolamayı nasıl başardınız? diye şaşkınlıkla sordum (Hossain 2007: 20).

Yerden denetlenen ve bulutlarn üzerinde yüzebilen bu balon sayesinde atmosferden istedikleri kadar su çekebiliyorlar, yağmur ve rüzgâr oluşumunu da kontrol edebiliyorlardı (Rokeya 2007: 21).

Şimdi anlıyorum neden ortalıkta hiç çamur olmadığını (Hossain 2007: 21).

Tarlalarını elektrik gücüyle sürülüyor ... hava araçları için de elektrikten yararlanıyorsunuz. Burada demiryolu ya da kaldırımları olan caddeler yok (Hossain 2007: 21).

Uzlaşmacı bir disiplin; karşılık gütmeyen bir işbirliği ve ölçülü bir hoşgörü anlayışının esas olduğu; rekabet yerine sorumluluk ve görev paylaşımı duygusunun öne çıkarıldığı kadınlar ülkesinde, Sultana'nın sorularına verilen yanıtlar; bireyin kimlik tanımını, ırk, din, sınıf, cinsiyet üstünlüğü üzerine kurmuş hiyerarşik erkek egemen iktidar kültürüne yönelik eleştiriler üzerine inşa edilir ve okura mevcut düzeni ve gerçekliği yadsıyan "alternatif bir dünya" yansitılır. Sultana'nın rehberine ait aşağıdaki cümleler yukarıda söylenenlerin Sultana'nın Rüyasi'ndaki yansımalarıdır.

Hepimiz doğadan verebildiğince almakla meşgulüz. Hiç boş oturmadığımız için birbirimizi yemeye de zaman kalmıyor. Yüce kraliçemiz botaniğe aşırı derece düşkün, bütün ülkeyi büyük bir çiçek bahçesine çevirme konusunda çok hevesli." (Hossain 2007: 26).

Sıcak dayanılmaz bir hal aldığında yapay kaynaklardan çekilen suyla çok sayıda fiskiye kullanılarak toprağı suluyoruz. Soğuk havalarda ise odalarımızı güneş enerjisiyle ısıtıyoruz (Hossain 2007: 26).

Selamlık sistemi kurulduğundan bu yana tek bir suç ve günah işlenmedi; dolayısıyla ne suçluyu bulmak için polise ihtiyacımız var, ne de suçluyu yargılaması için bir yargıca (Hossain 2007: 25).

Bizim dinimiz doğruluk ve sevgi üzerine kurulmuştur. Birbirini sevmek ve doğru olmak dini görevimizdir (Hossain 2007: 26).

Tanrının yarattı̆̆ı bir varlığı öldürmekten zevk almayız, hele bu bir insansa. Yalan söyleyene, bu ülkeden sonsuza dek gitmesini ve bir daha asla geri gelmemesini söyleriz (Hossain 2007: 27). 
Bizim dinimizde sınılar çok geniş, uzaktan erkek akraba bile erkek kardeş gibi kabul görüyor (Hossain 2007: 27).

Başkalarının ülkelerine göz dikmeyiz biz... bin kat parlak bile olsa, bir elmas parçası için savaşmayız, ... bilgi okyanusuna dalar, doğanın deposunda bizim için sakladığı değerli taşları bulmaya çalışııız, doğanın hediyelerinden olabildiğince zevk almaya bakarız (Hossain 2007: 28).

Kadınlar ülkesi topraklarına "saflığın kendisinin hükmettiğini" yazan Rokeya, zihninin özgürlügünde yolculuğa çıarır bizleri . Virgina Woolf'un A Room of One's Own (Kendine Ait Bir Oda) da dillendirdiği gibi "zihnimin özgürlüğüne vurabileceğiniz ne bir kilit var ne de sürgü, ne de kapatabileceğiniz bir kapı" (2016: 6) diyerek sınır tanımayan düşlerini resmeder okuyucunun bilincine. Özgür kişilerin var olduğu ortamlarda var olabilmek, Begüm Rokeya'nın özgür olabilmek için gereksinim duyduğu en önemli şeydir. Çünkü insanın var oluş alanı diğer insanlarla paylaştığı dünyasıdır. Bu yüzden yazar, özgür kişilerin var olduğu ortamları hayal eder. Diğer insanlarla paylaştığımız bu dünyada diğerlerini ve diğerinin özgürlüğünü yok saymadığımız bir ülke düşü kurar. Mevcut toplumsal uygulamaların yanlışlığını gösteren Begüm Rokeya, her şeyi tersine çevirerek yarattığı yabancılaşma duygusuyla okuyucuyu sarsar ve zihinsel bir değişim yaratır. Simon de Beauvoir'ın, "kadınların mutlak değerini göz ardı etmek, ona nesne muamelesi yapmak, ona şiddet uygulamaktan başka bir şey değildir" (Simons 2004: 190) düşüncesinin Güney Asya'daki sesidir Begüm Rokeya. Bu şiddetin karşısında, her şeyin suç ve günah olarak algılandığı böyle bir çağda ve toplumda, İkinci Cins kitabının önsözündeki "varoluşçu etik" anlayışını, düşünerek, hissederek ve sorgulayarak yıllar önce keşfetmiş ve "kendi özgürlüğü"nü istemenin diğerlerinin özgürlüğünü istemekle aynı şey olduğunu, yazdığı bu eserinde gözler önüne sermiştir.

Bilinç oluşturmanın yanı sıra kadınları geleceği değiştirmek için eyleme geçmeye çağıran Sultana'ın Rüyası, Sargent'in ifadesiyle mevcut duruma karşı duruş olarak ortaya çıkan bir toplumsal tasarım, gerçek anlamda toplumsal görünümlü bir eylem programıdır (2004: 96-97).

\section{SONUÇ}

"Kaçınılmazlıklara bir kere meydan okunduktan sonra, umuda yolculuk için erzak toplamaya başlarız" der Williams. Yazarak meydan okur Begum Rokeya; büyük bir cesaret, büyük bir sorumluluk ve hiç bitmeyen umuduyla. Sadece düşündügünüu söylemek değil; bize dayatılan düşüncelerin ötesinde düşünebilmek cesaretini gösterebilmek için çıkar bu yolculuğa. Farklı bir dünyaya yapılan bu yolculuk içsel yolculuğunun da bir metaforudur aslında. Yol sonunda ulaşılan nihai hedeften çok yol boyunca devam eden keşfe odaklanır Begüm Rokeya. Kıyıda kalmış olanları anlayabilmek, kendini onların yerine koyabilmek, aklın yanı sıra sezgilerin gücüne güvenebilmek; sessizliğin sesini duyup, dile getirilemeyeni dile getirmek, var olan dünyayı ve toplumu başka bir gözle algılayıp yansıtabilmeyi olanaklı kılmak için kurgular yeni bir dünyayı. Duvarda bir gedik açabilmek adına yazdığı Sultana'nın Rüyası ile duvarın çatlağından yol alırken; yazar başka dünyaların da mümkün olabileceği düşü ile baş başa bırakır okuyucusunu her gün korkunç şeylerin yaşandığı bu dünyada. 


\section{SUMMARY}

Utopia, the land of nowhere and good, has been the hope of Western ideology for centuries. As a literary term, utopia was first used by Sir Thomas More in his 1516 book "Utopia" which describes a fictional ideal society on an imaginary island. This word has an intentional double meaning, it is a pun on "ou (the Greek word for no) and "eu" (the Greek word for good); and topus means "place" in Greek. Thus, outopia is the imagined "no place" and eutopia is the idealized "good place". This idealized good and no places have one characteristic in common; the dissatisfaction with the present world order.

From the very first examples of literary utopias, there is a quest for a better world to live on. This literary genre has been defined repeatedly as a process of becoming better and more perfect from different point of views. Utopian writing offers writers what they want to preserve about the present society and what they want to discard from the social ills of the present. Essentially, human societies are living and changing organizations which strive for perfection. However, these both past and contemporary societies have been unable to reach this perfection, so these lands of dreams have deluded their writers and readers with the voyages to possible idealized lands. In their ideal states, utopian writings question what it means a society, democracy, hierarchy, equality, education, parenting, family, religion which are the main constituents of the patriarchal capitalism.

Utopian writers, intentionally or unintentionally, have been stayed aloof the problem of gender for thousands of years. Gender in human society is a burden especially for women. While satirizing and criticizing the contemporary societies, male utopian writers have hesitated to present possible solutions for patriarchal tyranny. Instead, they have strengthened the existing roles given to both men and women as the angel of the house who lived happily ever after.

Feminist utopias, for about ages, reflect the hopes, fears and desires of women who have glimpsed the possibilities of a bright new world freed from stifling patriarchal structures by presenting new horizons for the language of sisterhood. By contrasting the present word with an idealized society, feminist utopias criticize the contemporary values and conditions and see masculine systems as the major cause of social and political problems as described in Begum Rokeya's feminist utopia Sultana's Dream.

R.S. Hossain, a pioneering Bengali Muslim feminist and educationist, with her imaginative and ambitious narrative Sultana's Dream (1905) provides a definite vision of what society could become if women were allowed to fully participate as citizens. The work projects the desire for a peaceful, efficient and egalitarian society, and predicts the possibility of obtaining that desire through greater freedom for women.

As a consequence, the present paper will focus on a woman on the edge of time, Begüm Rokeya Sakhawat Hossain, her short work, Sultana's Dream, originally written in English. This study will highlight how she tries to create an ideal world, believing in the importance of education as holding the key to women's empowerment and progress. This paper will also concern itself with her personal journey on the road not taken before, the awakening of the Muslim women's self respect through self-reliance, and the universalist concept of shared humanity that admits no discrimination of caste, creed, race or gender.

SEFAD, 2017 (38): 407-418 


\section{KAYNAKÇA}

AĞAOĞLULARI, Mehmet Ali-KÖKER, Levent (1997). Tanrı Devletinden Kral Devlete. Ankara: İmge Kitabevi.

BAGCHİ, Biman (2005). "Introduction". Sultana's Dream and Padmarag. India: Penguen Books. BORGHI, Liana (2003). "Feminism (Amerikan)". Ütopyalar Sözlü̈̆̈̈. çev. Turhan Ilgaz. İstanbul: Sel Yayıncilık.

ÇAKIR, Serpil-AKGÖKÇE, Necla (1995). "Türkiye'de Kadın Tarihini Yazmak". Farklı Feminizmler Açısından Kadın Araştırmalarında Yöntem. İstanbul: Sel Yayıncılık. 222-230.

DİREK, Zeynep (2016). Cinsiyeti Yazmak. İstanbul: Yapı Kredi Yay.

DONOVAN, Josephine (2005). Feminist Teori: Amerikan Feminizminin Entellektüel Geleneği. çev. A. Bora, M. A. Gevrek ve F. Sayılan. İstanbul: İletişim Yay.

ERSOY, Yeşim (2007). "Bir Feminist Ütopya Modeli Olarak Charlotte Perkins Gilman'ın Kadınlar Ülkesi". Kültür ve Siyasette Feminist Yaklaşımlar. $\quad$ http://www.feministyaklasımlar.org/magazine.php?act:viewal\&cid:89 [09.10.2016].

FORBES, Geraldine (1996). Women In Modern India. Cambridge: University Press.

HOSSAIN, Anowar (2003). Muslim Women's Struggle For Freedom in Colonical Begal (18731940). Kalkota: Progresive Publishers.

HOSSAIN, Begum Rokeya Sakhawat (2007). Sultana'nın Rüyası ve Padmarag. çev. Billur Yılmazyiğit. İstanbul: Versus Yay.

JAHAN, Roushan (1988). A Feminist Utopia and Selections From the Secluded Ones. New York: A Feminist Press.

KELLER, Evelyn Fox (2007). Toplumsal Cinsiyet ve Bilim Üzerine Düşünceler. çev. Ferit B. Aydar. İstanbul: Metis Yay.

KUMAR, Krishan (2005). Ütopyacılık. çev. Ali Somel. Ankara: İmge Kitabevi.

LANE, A. J. (2007). "Önsöz". Kadınlar Ülkesi. Charlotte Perkins. çev. Meryem Kutlu. İstanbul: Otonom Yayıncilik.

MILLET, Kate (1987). Cinsel Politika. çev. Seçkin Selvi. İstanbul: Payel Yay.

MİAH, Mohammad Maniruzzaman (2014). "A Feminist Critical Evaluation of Haw Rokeya Sakhawat Hossain's Language of Protest Replored Patriarchy and Social Anachrohism in the British Bengal". Journal of Arts \& Humanities 04 (10): 41-51.

ÖĞÜT, Hande (2007). "Kadınlardan Feminist Ütopyalar". Varlık Dergisi. Mart.

SARGENT, Lymann Tower (2004). "Ütopya Gelenekleri: İzlekler ve Varyasyonlar". Kitaplık. s. 76.

SIMONS, Margaret (2004). "Moral Idealism and Political Realism". Simone de Beauvoir: Philosophical Writings. Chicago: University of Illinois Press.

WELLS, Herbert George (2007). "Ütopyalar". Başka Dünyalar Mümkün. der. K. Murat Güney. çev. Elif Çopuroğlu. İstanbul: Varlık Yay.

WOOLF, Virginia (2016). Kendine Ait Bir Oda. çev. İlknur Özdemir. İstanbul: Kırmızı Kedi Yayıncilik.

YILDIRMAZ, Yasemin (2005). Ütopyanın Kadınları Kadınların Ütopyası. İstanbul: Sel Yayıncılik.

YILDIRMAZ, Yasemin (2007). "Önsöz". Sultana'nın Rüyası ve Padmarag. çev. B. C. Yllmazyiğit. İstanbul: Versus Yay.

YILMAZYIĞİT, Billur (2007). "Arka Kapak". Sultana'nın Rüyası ve Padmarag. çev. B. C. Yllmazyiğit. İstanbul: Versus Yay.

ZAMAN, Niyaz (2003). A Celebration of Women. Dhaka: Akademic Press and Publishers Limited. 